\section{Aphids of ornamental plants and winter vegetables and their aphidiine parasitoids (Hymenoptera: Braconidae) in Aligarh region, Uttar Pradesh}

\author{
Uzma Rafi ${ }^{1}$, Mohd. Kamil Usmani ${ }^{2}$ \& \\ Mir Samim Akhtar ${ }^{3}$ \\ 1,2 Department of Zoology, Aligarh Muslim University, Aligarh, \\ Uttar Pradesh 202002, India \\ ${ }^{3}$ Division of Entomology, Indian Agricultural Research Institute, \\ New Delhi 110012, India \\ Email: ${ }^{2}$ usmanikamil94@gmail.com (corresponding author)
}

India has tremendous scope for the earning of foreign exchange by exporting ornamental plants and cut flowers round the year. The production of Roses, Carnations, Chrysanthemums and Gladioli at a very cheaper rate is possible in our country but still cannot compete with other nations (Holland and China) due to lack of proper transportation facility at required time. At present the floriculture in the country is not only meeting the domestic requirements, but its export has gone up to ₹ 78 (Indian National Rupees) crores ( 1 crore $=10$ million) in 1998 and only from Roses ₹ 75.17 crores (Atwal \& Dhaliwal 2002).

On the other hand, vegetables provide adequate quantities of vitamins, proteins, carbohydrates and minerals. The existing area under vegetable cultivation in India is around 7.98 million hectare with a production of about 129.08 million metric tones. In terms of production, India is second only to China (Johnson et al. 2008;

Date of publication (online): 26 August 2010

Date of publication (print): 26 August 2010

ISSN 0974-7907 (online) | 0974-7893 (print)

Editor: R.K. Avasthi

Manuscript details:

Ms \# o2399

Received 06 February 2010

Finally accepted 07 July 2010

Citation: Rafi, U., M.K. Usmani \& M.S. Akhtar (2010). Aphids of ornamental plants and winter vegetables and their aphidiine parasitoids (Hymenoptera: Braconidae) in Aligarh region, Uttar Pradesh. Journal of Threatened Taxa 2(9): 1162-1164.

Copyright: (c) Uzma Rafi, Mohd. Kamil Usmani \& Mir Samim Akhtar 2010. Creative Commons Attribution 3.0 Unported License. JoTT allows unrestricted use of this article in any medium for non-profit purposes, reproduction and distribution by providing adequate credit to the authors and the source of publication.

Acknowledgements: The authors are greatly thankful to Prof. Asi Ali Khan, Chairman, Department of Zoology, Aligarh Muslim University, Aligarh for providing necessary facilities through out study. Thanks are also due to Prof. Shujauddin for his guidance and Mrs. Asna Ghani for her help during course of study.

\section{OPEN ACCESS I FREE DOWNLOAD (C) (i) (4)}

Indiastat 2010).

Both the vegetable crops and ornamental plants are heavily attacked by aphids. Aphid parasitoids (Aphidiine) are very important control agents for aphid pests in a variety of agricultural and horticultural crops (Hagvar \& Hofsvang 1991). Aphidiines are specific solitary endophagus parasitoids of Aphids (Stary 1970; Stary \& Ghosh 1983). In the present study an attempt was made to parasitoids complex of aphids associated with winter vegetables and ornamental plants in Aligarh.

Material and Methods: The collections of host insects were made during the period from October to March, 2005-06 in Aligarh, Uttar Pradesh. Small twigs of host plants, infested with colonies of aphids, were brought to the laboratory and their cut ends were placed in water to prevent quick withering of the leaves. During the collection, every care was taken to avoid the mixing of different species. As soon as the parasitized aphids were mummified, they were separated in different tubes covered with muslin cloth. A slip was fixed to each tube indicating serial number, host, date and place of collection. Some healthy aphids were preserved in $80 \%$ alcohol with few drops of glycerin for the proper identification of host species. The tubes were examined daily in the morning for the emerged parasitoids. After emergence parasitoids were transferred to separate tubes. Later on, the parasitoids were killed by the vapours of ethyl acetate. The dead parasitoids were collected by means of a brush kept in $80 \%$ alcohol. Some specimens were mounted on triangular cards for proper identification.

Results and Discussion: The present study is confined to the aphidiine parasitoids complex of aphids associated with winter vegetables and ornamental plants in Aligarh. Fourteen different winter vegetables and 13 ornamental plants were found in this region (Table 1). There are 14 species of aphids found to be attacked on all these species of plants, out of these only Pentalonia nigronervosa is found as monophagus species while other are polyphagus. Among them Aphis craccivora, A. corrianderi, A. gossipii, Acrythosiphon pisi, Bravicoryne brassicae, Lipaphis erysimi, Myzus persicae, Pentalonia nigronervosa, were observed as a regular pests of 12 plant species (Table 1), while Aphis gossipii, A. fabae, M. persicae, were also serious pest of four plant species though sporadic nature (Table 1). Macrosiphoniella sanborni, Hydaphis corriandri, Pentalonia nigronervosa, Lipaphis erysimi, Acrythosiphone pisi, Macrosiphum rosaeformes, were regular pests of six plant species. Aphis craccivora, Uroleucon compositae, Aphis fabae, Aphis spiraecola, Aphis gossypii, Rhopalosiphum nymphae were observed as sporadic pests of seven plant species (Table 1).

Seven species of aphidiine parasitoids viz., Aphidius colemani Viereck, Aphidius smithi Subba Rao \& Sharma, 
Table 1. Incidence of aphids in Aligarh

\begin{tabular}{|c|c|c|c|c|c|}
\hline & Plants & Aphids & Aphidiine parasitoids & $\begin{array}{l}\text { Intensity } \\
\text { of aphids }\end{array}$ & $\begin{array}{l}\text { Incidence } \\
\text { of aphids }\end{array}$ \\
\hline \multicolumn{6}{|c|}{ Ornamental plants } \\
\hline 1. & Argimon sp. & Aphis crccivora Koch & $\begin{array}{l}\text { Lipolexis oregmae (Gahan) } \\
\text { L. gracilis Foerster }\end{array}$ & * & Sporadic \\
\hline 2. & Bougainvillea sp. & Aphis craccivora Koch & $\begin{array}{l}\text { Lipolexis oregmae (Gahan) } \\
\text { L. grecilis Foerster }\end{array}$ & * & Sporadic \\
\hline 3. & Calendula & Uroleucon compositae Theob & Nil & * & Sporadic \\
\hline 4. & Castrum nocturnum & Aphis fabae solanella Theob & $\begin{array}{l}\text { Binodoxys indicus (Subba Rao \& } \\
\text { Sharma) }\end{array}$ & * & Sporadic \\
\hline 5. & Chrysanthemum sp. & Macrosiphoniella sanborni (Gillette) & Nil & $* \star *$ & Regular \\
\hline 6. & Coriander & Hyadaphis coriandri Das & Nil & ** & Regular \\
\hline 7. & Cosmos & Aphis spiraecola Patch & Nil & * & Sporadic \\
\hline 8. & Hibiscus rosa-sinensis & Aphis gossypii Glover & B. indicus (Subba Rao \& Sharma) & * & Sporadic \\
\hline 9. & Ornamental Banana & Pentalonia nigronervosa Cock. & Nil & $* * *$ & Regular \\
\hline 10. & $\begin{array}{l}\text { Ornamental Cabbage } \\
\& \text { Kale }\end{array}$ & Lipaphis erysimi (Kalt.) & Diaeretiella rapae (M'Intosh) & $* * *$ & Regular \\
\hline 11. & Lathyrus odoratus & Acrythosiphon pisi (Kalt.) & Aphidius smithi Subba Rao \& Sharma & ** & Regular \\
\hline 12. & Rose & Macrosiphum roseiformis Das & Nil & $* \star *$ & Regular \\
\hline 13. & Verbena & Rhopalosiphum nymphae (Linn.) & Nil & * & Sporadic \\
\hline \multicolumn{6}{|c|}{ Winter Vegetables } \\
\hline \multirow{2}{*}{14.} & \multirow{2}{*}{ Brinjal } & Myzus persicae (Schulz) & Aphidius colemani Viereck & * & Sporadic \\
\hline & & Aphis gossypii Glover & B. indicus (Subba Rao \& Sharma) & * & Regular \\
\hline 15. & Beans & Aphis crccivora Koch & L. oregmae (Gahan) & ** & Regular \\
\hline 16. & Banana & Pentalonia nigronervosa Cock. & Nil & ** & Regular \\
\hline \multirow{2}{*}{17.} & \multirow{2}{*}{$\begin{array}{l}\text { Bathua (Chenopodium } \\
\text { sp.) }\end{array}$} & Aphis fabae Theobalt & L. oregmae (Gahan) & * & Sporadic \\
\hline & & A. gossypii Glover & B. indicus (Subba Rao \& Sharma) & * & Sporadic \\
\hline 18. & Cauliflower & Lipaphis erysimi (Kalt.) & D. rapae (M'Intosh) & $* * *$ & Regular \\
\hline 19. & Cabbage & L. erysimi (Kalt.) & D. rapae (M'Intosh) & $* * *$ & Regular \\
\hline \multirow{2}{*}{20.} & \multirow{2}{*}{ Mustard } & \multirow{2}{*}{ L. erysimi (Kalt.) } & D. rapae (M'Intosh) & $* * *$ & Regular \\
\hline & & & L. gracilis Foerster & & \\
\hline 21. & Potato & M. persicae (Schulz) & L. oregmae (Gahan) & $* * *$ & Regular \\
\hline 22. & Pea & Acrythosiphon pisi Kalt. & Aphidius smithi Subba Rao \& Sharma & ** & Regular \\
\hline \multirow{2}{*}{23.} & \multirow{2}{*}{ Papaya } & M. persicae (Schulz) & Lysaphidus qadrii Shuja-Uddin & * & Sporadic \\
\hline & & A. gossypii Glover & B. indicus (Subba Rao \& Sharma) & * & Sporadic \\
\hline 24. & Saunf & Hyadaphis corrianderi Koch. & L. gracilis Foerster & ** & Regular \\
\hline \multirow{2}{*}{25.} & \multirow{2}{*}{ Raddish } & L. erysimi (Kalt.) & D. rapae (M'Intosh) & $* * *$ & Regular \\
\hline & & Brevicoryne brassicae L. & D. rapae (M'Intosh) & ** & Regular \\
\hline \multirow{3}{*}{26.} & \multirow{3}{*}{ Tomato } & \multirow{2}{*}{ M. persicae (Schulz) } & L. qadrii Shuja-Uddin & ** & Regular \\
\hline & & & A. colemani Viereck & & \\
\hline & & A. gossypii Glover & B. indicus (Subba Rao \& Sharma) & * & Sporadic \\
\hline \multirow{2}{*}{27.} & \multirow{2}{*}{ Turnip } & L. erysimi (Kalt.) & D. rapae (M'Intosh) & $* * *$ & Regular \\
\hline & & B. brassicae L. & D. rapae (M'Intosh) & ** & Regular \\
\hline
\end{tabular}


Binodoxys indicus (Subba Rao \& Sharma), Diaeretiella rapae (M'Intosh), Lipolexis gracilis Foerster, Lipolexis oregmae (Gahan), Lysaphidus qadrii Shujauddin were found parasitizing nine aphid species (Table 1).

\section{REFERENCES}

Atwal, A.S. \& G.S. Dhaliwal (2002). Agricultural Pest of South - East Asia \& Their Management. Kalyani Publisher, New Delhi, $321 \mathrm{pp}$.

Hagvar, E.B. \& T. Hofsvang (1991). Aphid parasitoids (Hymenoptera: Aphidiidae) biology, host selection and use in biological control. Biological News and Information 12: 1341.
Indiastat (2010). State-wise Production of Vegetables in India (2004-2005 to 2008-2009) http://www.indiastat.com/ agriculture/2/vegetables/17427/totalvegetables/17459/stats. aspx Dated 20.VIII.2010

Johnson G.I., W.K. Katinka \& M.H. Wu (2008). The Vegetable Industry in Tropical Asia: India. An Overview of Production and Trade. AVRDC - The World Vegetable Center, Shanhua, Tainan, Taiwan, 74pp.

Stary, P. (1970). Biology of Aphid Parasites (Hymenoptera: Aphidiinae) with Special Respect to Integrated Control. Series Entomologica, W. Junk, Hague, 643pp.

Stary, P. \& A.K. Ghosh (1983). Aphid Parasitoids of India and Adjacent Countries (Hymenoptera: Aphidiidae). Technical Monograph No. 7, Zoological Survey of India, 96pp. 